\title{
The BCR-ABL/NF-KB signal transduction network: a long lasting relationship in Philadelphia positive Leukemias
}

\author{
Giovanna Carrà ${ }^{1}$, Davide Torti ${ }^{1}$, Sabrina Crivellaro ${ }^{1}$, Cristina Panuzzo ${ }^{1}$, Riccardo \\ Taulli ${ }^{2}$, Daniela Cilloni ${ }^{1}$, Angelo Guerrasio ${ }^{1}$, Giuseppe Saglio ${ }^{1}$ and Alessandro \\ Morotti $^{1}$ \\ ${ }^{1}$ Department of Clinical and Biological Sciences, University of Turin, Orbassano, Italy \\ 2 Department of Oncology, University of Turin, Orbassano, Italy \\ Correspondence to: Alessandro Morotti, email: alessandro.morotti@unito.it \\ Keywords: BCR-ABL; NF-KB; IKB-G; NFKBIA; CML
}

Received: April 17, $2016 \quad$ Accepted: August 10, 2016

Published: August 22, 2016

\section{ABSTRACT}

The Nuclear Factor-kappa B (NF-kB) family of transcription factors plays a key role in cancer pathogenesis due to the ability to promote cellular proliferation and survival, to induce resistance to chemotherapy and to mediate invasion and metastasis. NF-KB is recruited through different mechanisms involving either canonical (RelA/p50) or non-canonical pathways (RelB/p50 or RelB/p52), which transduce the signals originated from growth-factors, cytokines, oncogenic stress and DNA damage, bacterial and viral products or other stimuli. The pharmacological inhibition of the NF-kB pathway has clearly been associated with significant clinical activity in different cancers. Almost 20 years ago, NF-KB was described as an essential modulator of BCR-ABL signaling in Chronic Myeloid Leukemia and Philadelphiapositive Acute Lymphoblastic Leukemia. This review summarizes the role of NF-KB in BCR-ABL-mediated leukemogenesis and provides new insights on the long lasting BCR-ABL/NF-KB connection.

\section{INTRODUCTION}

The Philadelphia chromosome $\left(\mathrm{Ph}^{+}\right)$refers to the translocation $\mathrm{t}(9 ; 22)$ and is the genetic hallmark of chronic myeloid leukemia (CML) and of about one third of acute lymphoblastic leukemias (ALL) [1-5]. $\mathrm{Ph}^{+}$ chromosome codes for the BCR-ABL chimeric protein which is characterized by the constitutive activation of the tyrosine kinase ABL [6-9]. The generation of the p210-BCR-ABL isoform is responsible for the CML phenotype, while the shorter p190-BCR-ABL isoform leads to the development of $\mathrm{Ph}^{+}$ALL [10]. However, the presence of p210-BCR-ABL isoform is not restricted to CML, as it is found in $10 \%$ to $20 \%$ of adults and in a small percentage of children with ALL[11-13]. Although BCRABL tyrosine kinase inhibitors (TKIs) have undoubtedly revolutionized the therapy of $\mathrm{Ph}^{+}$leukemias [14,15], both CML and ALL are not completely eradicated by BCRABL inhibition, as extensively reviewed elsewhere [1620]. In particular, the major unmet clinical needs in the field of $\mathrm{Ph}^{+}$leukemias are represented by: i) the incomplete eradication of CML chronic phase, ii) the need for a better control of CML blast phase [21] and iii) the improvement of TKIs efficacy in $\mathrm{Ph}^{+} \mathrm{ALL}$ [22]. Therefore, the molecular dissection of BCR-ABL signaling network is advisable to identify the signaling axes which are essential for the maintenance of $\mathrm{Ph}^{+}$leukemias and whose inhibition allows to achieve synthetic lethality together with BCRABL TKIs. Synthetic lethal therapies, designed to target those synthetic lethal partners of genetic aberrations found in cancers, allow to selectively target cancer cells while sparing normal cells, as extensively reviewed [23]. In accordance with this notion, tandem inhibition of NF- $\mathrm{KB}$ signaling proteins together with potential synergistic pathways has always appeared as an attractive strategy. The Nuclear Factor-kappaB (NF-kB) family of transcription factors was originally investigated in the immune system due to its ability to regulate the expression of cytokines and effector enzymes, especially in response to the activation of several receptors involved in immunity, including $\mathrm{T}$ and B-cell receptors [24, 25]. Furthermore, the NF- $\mathrm{kB}$ pathway has been linked to the regulation of 
several processes involved in tumorigenesis [26,27]. These include proliferative signaling [28], cell death evasion $[29,30]$ and resistance to chemotherapy [31]. Therefore $\mathrm{NF}-\kappa \mathrm{B}$ signaling was early identified as a potential target for cancer therapy [32,33]. Moreover, almost 20 years ago NF-kB was described as a key BCR-ABL partner [34-36]. Since then, various reports have further investigated the contribution of different $\mathrm{NF}-\kappa \mathrm{B}$ components in $\mathrm{CML}$ and $\mathrm{Ph}^{+} \mathrm{ALL}$ pathogenesis. These results have allowed a better understanding of $\mathrm{NF}-\kappa \mathrm{B}$ signaling and have drawn particular attention on its targeting in $\mathrm{Ph}^{+}$leukemia context. In this review, we will consider the BCR-ABL/ $\mathrm{NF}-\kappa \mathrm{B}$ crosstalk with relation to the development and maintenance of leukemia and we will debate the potential therapeutic strategies to block NF-кB signaling in $\mathrm{Ph}^{+}$ malignancies.

\section{NF-kB signaling}

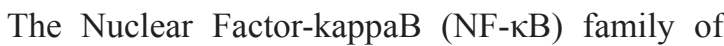
transcription factors mediates various biological processes which can be deregulated in cancer pathogenesis and involved in generating resistance to chemotherapy. Consequently, the experimental dissection of the NF- $\kappa \mathrm{B}$ signaling network offers new opportunities to exploit therapeutically the inhibition of the pathway [27, 3741]. NF- $\kappa \mathrm{B}$ members comprise two protein subfamilies which are synthesized as large precursors, namely Rel and NF- $\kappa \mathrm{B}$. In turn, the Rel family includes RelA (also known as p65), RelB and c-Rel, while NF- $\kappa$ B members are p50 (that originates from the p105 precursor) and p52 (that originates from the p100 precursor). They are also called $\mathrm{NF}-\kappa \mathrm{B} 1$ and $\mathrm{NF}-\kappa \mathrm{B} 2$ respectively and are able to form hetero- and homo-dimers. The NF- $\kappa \mathrm{B}$ pathway is modulated by negative or positive regulatory elements associated with canonical and non-canonical pathways (Figure 1). The canonical pathway is based on the negative regulation of $\mathrm{I} \kappa \mathrm{B}-\alpha[42,43]$, which retains $\mathrm{p} 65 /$ p50 heterodimers in the cytoplasm in a latent state, thus inhibiting their binding to DNA. Various stimulations such as cytokines, growth factors, LPS and other stimuli, promote the activation of the IKK kinase complex, which in turn phosphorylates I $\mathrm{KB}-\alpha$ on serine residues [44-46]. This event primes I $\mathrm{B}-\alpha$ to ubiquitination and its consequent degradation through the proteasome. Upon I $\mathrm{B}-\alpha$ degradation, $\mathrm{p} 65 / \mathrm{p} 50$ complex translocates into the nucleus where it binds to the enhancer or promoter regions of specific DNA sequences and promotes transcription of target genes. NFKBIA, the gene encoding for I $\kappa \mathrm{B}-\alpha$, is one of the first genes to be induced, providing a mechanism of negative feedback $[47,48]$. The non-canonical pathway relies on the p50 and p52 subunits, as reviewed elsewhere $[49,50]$. In particular, the kinase NIK (NF- $\kappa \mathrm{B}$ inducing Kinase) is able to activate IKK- $\alpha$ complex which mediates p100 phosphorylation. This results in the proteasomedependent processing of p100 to p52, driving activation of RelB/p52 heterodimers that in turn target distinct $\kappa \mathrm{B}$ elements on DNA[51]. NF- $\kappa \mathrm{B}$ is known to regulate several cellular processes, including proliferation [28], protection from apoptosis [29, 30, 52], cell cycle [53], cell migration and angiogenesis [54] and resistance to chemotherapy[31]. Due to this broad spectrum of effects, deregulation of $\mathrm{NF}-\kappa \mathrm{B}$ signaling has been strongly associated with the development of several diseases, including hematological cancers [55-57]; however, NF- $\mathrm{B}$ family members mutations, which induce its constitutive activation, are rare events in hematological malignances [55]. It is clear that the two pathways of NF-kB differ in their signaling mechanisms. Moreover, increasing evidence suggests that the non-canonical pathway regulates important biological functions in the lymphoid compartment, such as lymph node organogenesis, B-cell development and survival and it is also found deregulated mostly in lymphoid malignancies [58]. In addition, it should be noted that the activation of $\mathrm{NF}-\kappa \mathrm{B}$ is in most cases a consequence of several other aberrantly activated pathways (for example EGF-R [59], HGF/c-MET [60], oncogenic Ras [61, 62], PI3K [63], AKT [64], SRC [65] and others).

\section{HISTORICAL PERSPECTIVE ON BCR- ABL/NF-KB RELATIONSHIP}

\section{Cell lines and cellular models}

The first observations that $\mathrm{Bcr}-\mathrm{Abl}$ regulates the NF- $\mathrm{B}$ signaling were made with the p210-BcrAbl-transformed DA1, an IL-3-dependent murine cell line [34]. In this cellular model, Bcr-Abl expression abrogated IL-3-dependent growth and enabled NF$\kappa \mathrm{B}$ to bind to DNA-responsive elements. Notably, the inhibition of RelA by antisense oligonuclotides reverted the IL-3-independence of Bcr-Abl-transformed DA1 cells, suggesting that NF- $\kappa \mathrm{B}$ may contribute to Bcr-Ablmediated tumorigenesis. Similar conclusions were drawn using the Bcr-Abl-expressing 32D cell line [35], an Il-3 dependent murine myeloblast-like cell line, where Reuther and colleagues further dissected the mechanisms of NF$\kappa \mathrm{B}$ activation by Bcr-Abl showing that Ras is required for the regulation of NF- $\mathrm{BB}$. In particular, RasA17 mutant, acting as a dominant negative protein, affects the ability of BCR-ABL to activate NF- $\kappa \mathrm{B}$. Notably, expression of an I $\kappa$ B- $\alpha$ isoform unable to be degraded, prevented NF$\kappa \mathrm{B}$ activation by Bcr-Abl. Thus, in the specific context of Bcr-Abl-dependent cells, NF- $\kappa \mathrm{B}$ appeared unnecessary to protect cells from death caused by IL-3 removal or treatment with DNA damage agents. However, a murine xenotransplantation model of Bcr-Abl-32D cells showed that $\mathrm{NF}-\kappa \mathrm{B}$ activation was necessary to mediate Bcr-Abl tumorigenesis, suggesting that in vitro cellular models may harbor mechanistic bias for the study of $N F-\kappa B$ 
signaling [35]. Other groups have subsequently confirmed the $\mathrm{Bcr}-\mathrm{Abl} / \mathrm{NF}-\kappa \mathrm{B}$ connection [66] in vitro. Using a Bcr-Abl-BaF3 cell line, a Il-3 dependent murine pro B cell line, it was shown that NF- $\kappa \mathrm{B}$ activation is partially dependent by $\mathrm{I} \kappa \mathrm{B}-\alpha$ degradation but independent of I $\mathrm{I} \mathrm{B}$ kinase (IKK) activity [36], while Ras appeared necessary for the activation of NF- $\mathrm{BB}$. This work described for the first time $\mathrm{NF}-\kappa \mathrm{B}$ activation in primary CML blast crisis [36]. In addition to the essential role of Ras, it was also demonstrated that various and complex mechanisms were responsible for triggering $\mathrm{NF}-\kappa \mathrm{B}$ activity. In particular, $\mathrm{NF}-\kappa \mathrm{B}$ activation is also dependent on downstream targets of Bcr-Abl including MEK kinase-1 (MEKK1). Bcr-Abl enhances MEKK1 expression and kinase activity which in turn strongly induces NF- $\kappa \mathrm{B}$ signaling. On the contrary, inhibition of MEKK1 with a dominant-negative mutant decreased NF- $\kappa \mathrm{B}$ activation [67]. Bcr-Abl can induce activation of the NF- $\kappa \mathrm{B}$ pathway in Bcr-Abl cells by Protein Kinase D2 (PKD2). It has been established that $\mathrm{Bcr}-\mathrm{Abl}$ induces activation of NF- $\mathrm{B}$ in LAMA84 cells, a human $\mathrm{CML}$ blast crisis cell line, through tyrosine phosphorylation of PKD2 [68] at Tyr438. Among the mechanisms by which NF- $\kappa \mathrm{B}$ can be activated by Bcr$\mathrm{Abl}$ it is worth mentioning that osteopontin -a protein produced and secreted by Bcr-Abl-expressing cells- can bind integrin receptors and regulate I $\mathrm{B}-\alpha$ expression in an autocrine manner [69]. Finally, by analyzing NF- $\kappa$ B network activity, it was pointed out a negative association between the expression of CUEDC2, which is associated with endocrine resistance in breast cancer, and $\mathrm{NF}-\kappa \mathrm{B}$ signaling. In particular knockdown of CUEDC2 in K562 cell line, a CML blast crisis cell line, causes an increase of IKK complex phosphorylation and favors I $\mathrm{I} B-\alpha$ degradation [70]. Altogether, these original contributions clearly suggest that: i) BCR-ABL is able to promote NF$\kappa \mathrm{B}$ activation in vitro; ii) Ras is necessary for NF-kB activation; iii) the contribution of I $\mathrm{B}-\alpha$ and IKK in the regulation of $\mathrm{NF}-\kappa \mathrm{B}$ is not entirely clear -at least in cell lines- and needs further studies in murine models (Figure 2).

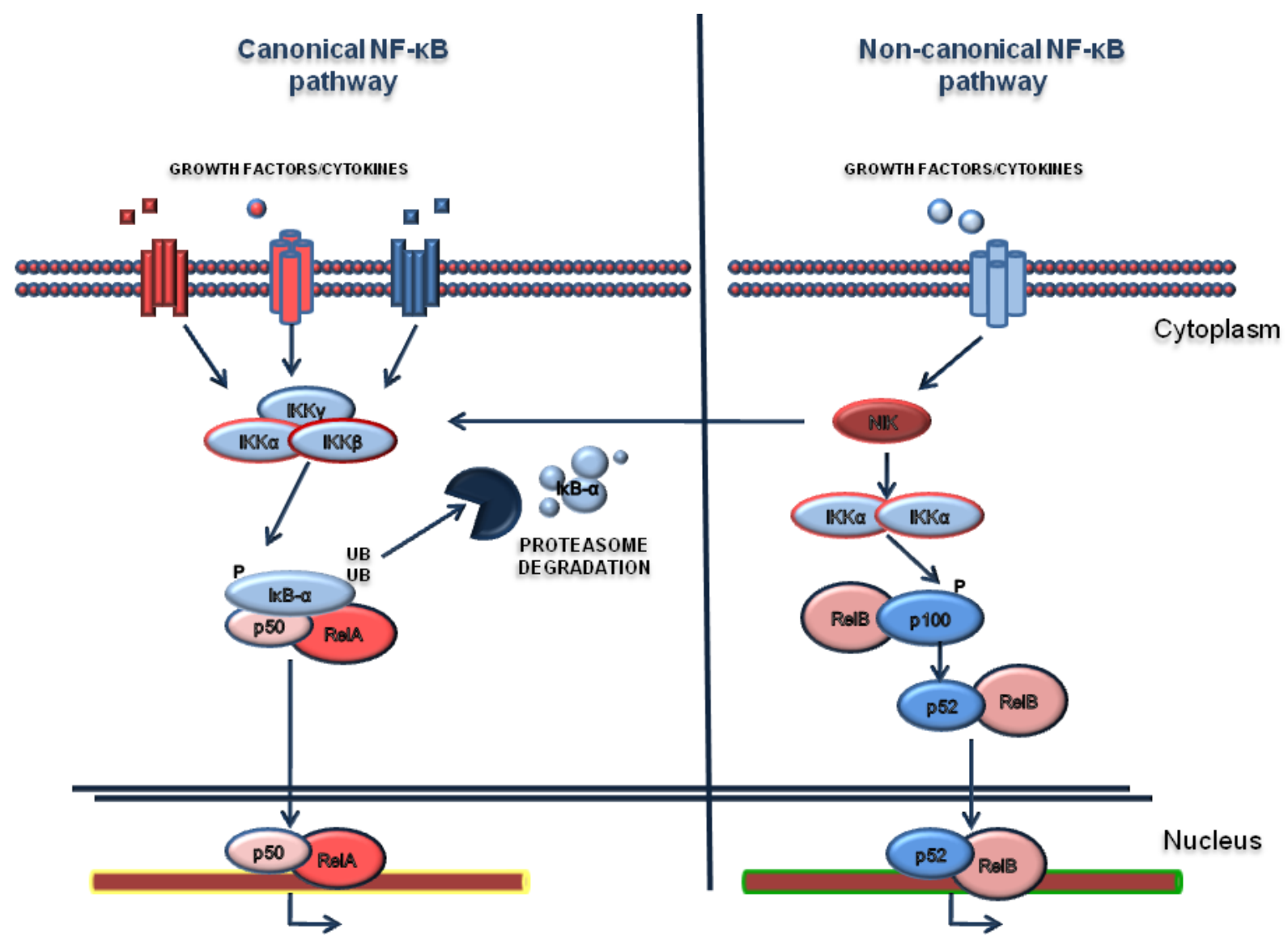

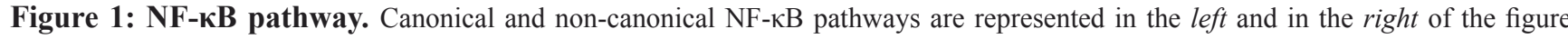
respectively. The activation of canonical pathway is mediated by various ligands such as Tumor Necrosis Factor (TNF $\alpha)$, Interleukin-1 (IL-1), or growth factors. The activation relies on the phosphorylation of IкB- $\alpha$ by the IKK complex and subsequent its degradation by the proteasome. Consequently, the RelA/p50 complex translocates to the nucleus where it activates the transcription of target genes. The non-canonical pathway is based on the activation of IKK $\alpha$ by the NF- $\mathrm{BB}$-inducing kinase (NIK), after stimulation. In turn the complex NIKIKK $\alpha$ phosphorylates the p100 subunit. As a consequence, p100 is processed in a proteasome dependent manner, generating the subunit $\mathrm{p} 52$. This event results in the activation of $\mathrm{p} 52-$ RelB that induces the transcription of distinct target genes. 


\section{Primary Philadelphia positive samples}

In human-derived primary $\mathrm{Ph}^{+}$leukemias the assessment of NF- $\mathrm{KB}$ activation led to different conclusions. In an original report based on electrophoretic mobility shift assay (EMSA) analysis, NF- $\mathrm{kB}$ was found highly active in CML blast crisis [36]. Similarly, other analyses with a group of myeloid neoplasms, including AML, chronic phase CML and blast phase CML, described that $\mathrm{NF}-\mathrm{\kappa B}$ is markedly active in CML blast crisis when compared to the chronic phase of the disease[71]. However, successive works which adopted different experimental approaches to measure NF- $\mathrm{kB}$ activity, showed that even the chronic phase of CML is associated with an increased NF- $\mathrm{kB}$ activation [72] when compared to normal bone marrow samples, suggesting a functional heterogeneity. Conversely, in $\mathrm{Ph}^{+} \mathrm{ALL}$, constitutive NF$\kappa \mathrm{B}$ activation may be considered a common feature of the disease [73]. As a general principle, NF- $\mathrm{kB}$ is more active in $\mathrm{Ph}^{+} \mathrm{ALL}$ and CML blast crisis with respect to the chronic phase disease. Apparent discrepancies among different reports could be explained either accordingly to different sensitivity of the methods used or related to population heterogeneity. Undoubtedly, the data available so far highlight the relevant role of NF- $\mathrm{BB}$ (regulation) in $\mathrm{Ph}^{+}$leukemias.

\section{Murine models}

Besides cell lines, murine models supply a good platform for studying the role of NF- $\mathrm{KB}$ in the pathogenesis and development of leukemias [74, 75]. Van Etten and colleagues showed in mouse models of $\mathrm{CML}$ and $\mathrm{Ph}^{+} \mathrm{B}-\mathrm{ALL}$ that NF- $\mathrm{kB}$ contributes to myeloid and lymphoid leukemogenesis through Bcr-Abl [76]. Primary bone marrow murine hematopoietic cells were infected to express both BCR-ABL and an IкB- $\alpha$ mutant

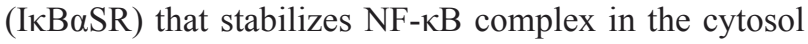
or dominant-negative, kinase-inactive, mutants of IKK [76]. Infections were performed to recapitulate $\mathrm{Ph}^{+} \mathrm{ALL}$ and CML-like phenotypes. In these models, I $\mathrm{KB} \alpha \mathrm{SR}$ and IKK mutants were shown to attenuate Bcr-Abl-mediated leukemogenesis and to prolong survival. Notably, authors demonstrated that NF-kB inhibition affects BCR-ABL leukemogenesis partially through the impairment of

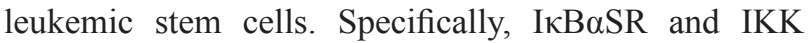

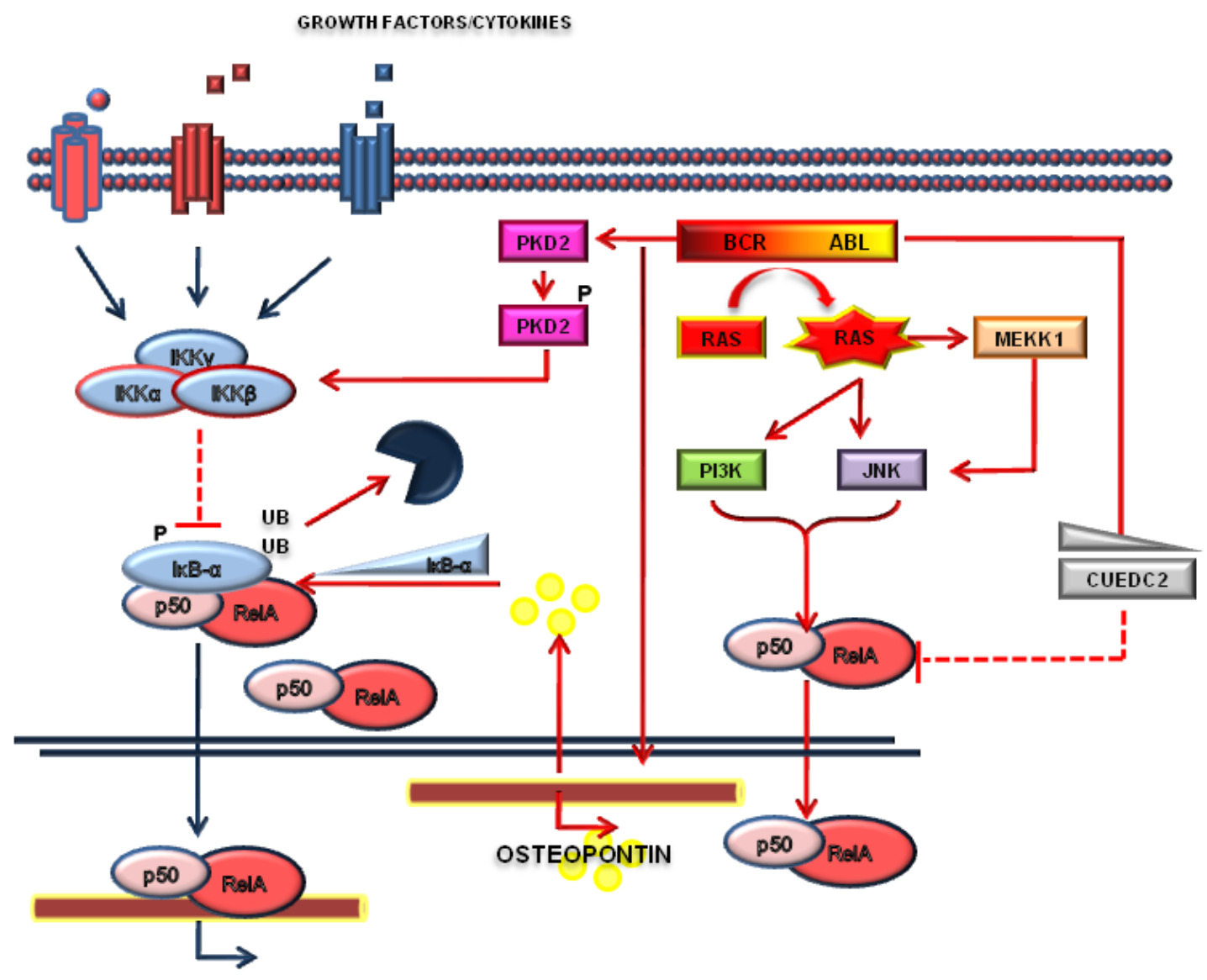

Figure 2: BCR-ABL/NF-KB crosstalk. Numerous pathways, including Ras, MEKK1, c-Jun N-terminal kinase (JNK) and protein kinase D2 (PKD2) are activated by the Bcr-Abl and converge on NF- $\kappa \mathrm{B}$ activation. NF- $\kappa \mathrm{B}$ activation is also under the regulation of osteopontin or CUEDC2, as indicated. 
mutants decrease the number of leukemia stem cells capable of initiating tumorigenesis [76]. Furthermore, using limiting dilution secondary transplantation of BM from CML mice, authors clearly demonstrated that SR$\mathrm{IkB} \alpha$ and IKK $\alpha$ mutant significantly affect the number of cells that are able to recapitulate the disease in the secondary recipient. Beside demonstrating that $\mathrm{IkB} \alpha$ and IKK are essential components of the BCR-ABL leukemogenesis, this work also demonstrated that $\operatorname{SRIkB} \alpha$ and IKK mutants significantly increase the sensitivity of $\mathrm{Ph}^{+}$cells to TKI. This work provided the first evidence that in vivo Bcr-Abl activates $\mathrm{NF}-\kappa \mathrm{B}$ through the classical (canonical) IKK/IкB- $\alpha$ pathway and strongly supports the rationale that therapies designed to target canonical NF- $\kappa \mathrm{B}$ network may be effective in $\mathrm{Ph}^{+}$leukemias. Furthermore, this preclinical in vivo model rules out most of the controversial results obtained with cellular models, and offers the chance to design clinical trials with IKK inhibitors in combination with TKI in highly challenging settings, such as the therapy of $\mathrm{Ph}^{+}$ALL and CML blast crisis.

\section{The contribution of the microenvironment}

NF- $\kappa \mathrm{B}$ signaling is also under the control of several cytokines produced by stromal cells or by the tumor itself
[42]. The Tumor Necrosis Factor- $\alpha$ (TNF- $\alpha)$ is one of the most important cytokines able to activate NF- $\mathrm{B}$ [77]. At the same time, TNF- $\alpha$ signaling was shown to be affected by Bcr-Abl [78]. In particular, ectopic expression of BCRABL promoted TNF- $\alpha$ receptor down-regulation with consequent impairment of TNF- $\alpha$ signaling. Recently, it was demonstrated that CML stem/progenitor cells secrete TNF- $\alpha$ in a Bcr-Abl Kinase-independent manner [79] promoting NF- $\kappa \mathrm{B}$ activation. Specifically, autocrine TNF- $\alpha$ production is able to sustain CML stem cells and progenitor cells survival and pharmacological targeting of the TNF- $\alpha / N F-\kappa B$ pathway is able to synergize with $\mathrm{Bcr}-\mathrm{Abl}$ inhibition to a relevant degree. Again, these observations point to a key role of the microenvironment in the regulation of $\mathrm{NF}-\kappa \mathrm{B}$ signaling in CML [79]. Similarly to TNF- $\alpha$, the TGF- $\beta$ signaling was also shown to play an essential role in CML biology [80-82]. Notably, TGF- $\beta$ orchestrates CML cellular destiny through a complex $\mathrm{PI} 3 \mathrm{~K} / \mathrm{AKT} / \mathrm{NF}-\kappa \mathrm{B} / \mathrm{MMP} 9$ pathway, which includes $N F-\kappa B$ [83]. Overall, these data suggest that NF- $\kappa B$ is regulated by the microenvironment where $\mathrm{Ph}^{+}$positive cells reside. In particular, both autocrine TNF- $\alpha$ secretion and cytokines produced from the environment are able to sustain NF- $\kappa \mathrm{B}$ signaling in CML cells. The presence of a $\mathrm{Bcr}-\mathrm{Abl}$ independent mechanism of NF- $\kappa \mathrm{B}$ activation in $\mathrm{Ph}^{+}$leukemias has two important implications. Firstly, it suggests that non-cell autonomous or micro-environmental

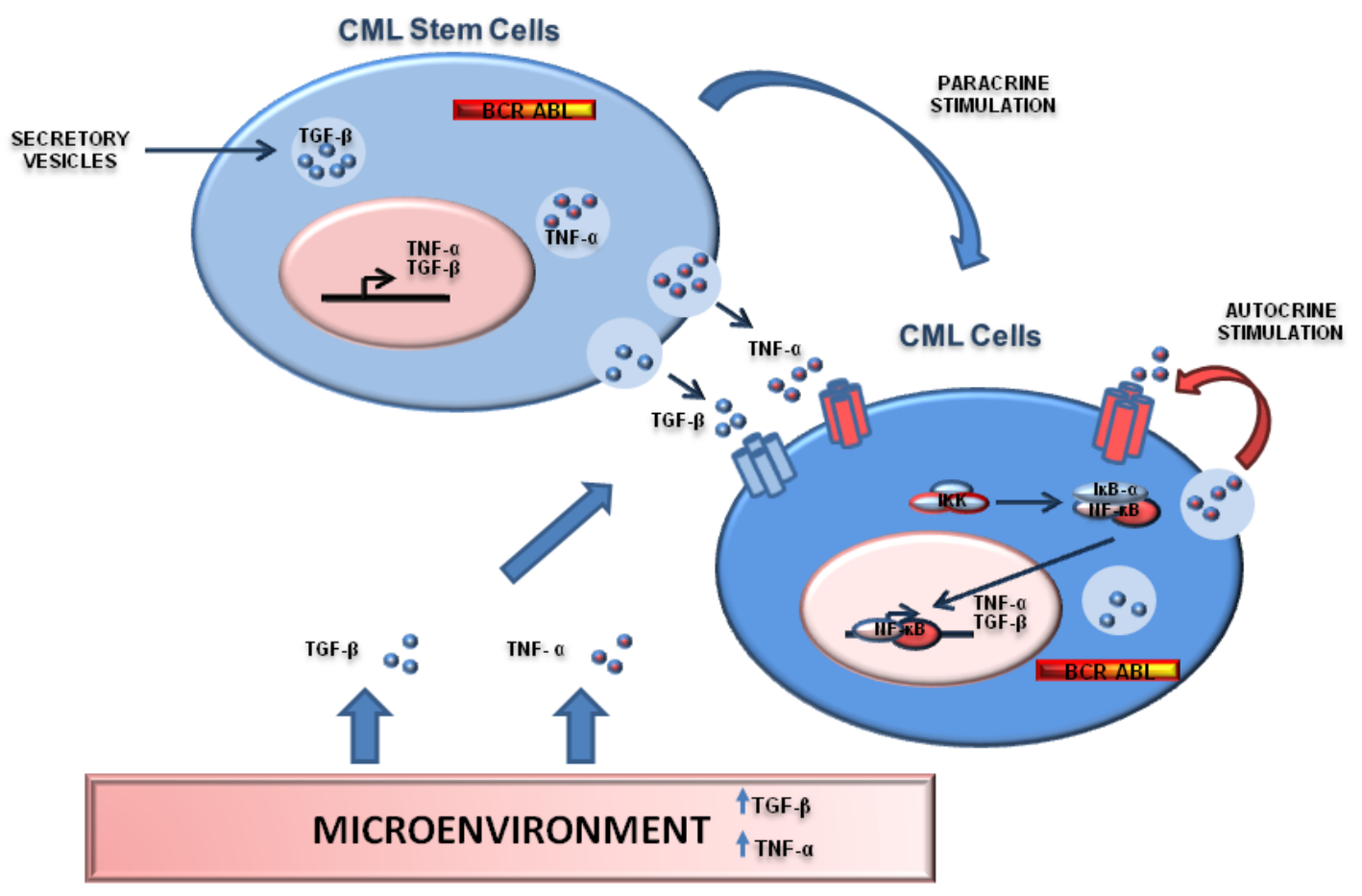

Figure 3: NF-кB is regulated by the environment where $\mathbf{P h}+$ positive cells reside. Interactions between $\mathrm{Ph}^{+}$stem/progenitor cells and stromal cells and representation of TGF- $\beta$ and TNF- $\alpha$ networks. Both TGF- $\beta$ and TNF- $\alpha$ can be secreted by CML cells as part of a autocrine/paracrine loop able to sustain NF-kB signaling. Moreover, $\mathrm{Ph}^{+} \mathrm{CML}$ cells can be regulated by TGF- $\beta$ and TNF- $\alpha$ produced by stromal cells or inflammatory cells. This mechanism may promote NF-kB signaling in a BCR-ABL-independent manner. 
processes are important in the maintenance of leukemias and therefore must be considered to design an effective targeted therapy for these cancers. Secondarily, the contribution of the stroma in the activation of NF- $\kappa \mathrm{B}$ may also explain most of the controversial results observed in cell lines $v s$ primary samples $v s$ murine models. For instance, IKK and I $\mathrm{KB}-\alpha$ appeared dispensable for NF$\kappa \mathrm{B}$ activation in some cell line models, while are clearly important in murine models or in primary cells. These discrepancies may be explained by the absence of the microenvironment, a source of TNF- $\alpha$ and TGF- $\beta$, in cell line experiments (Figure 3).

\section{THERAPEUTICAL IMPLICATIONS}

The important role of $\mathrm{NF}-\kappa \mathrm{B}$ in tumor cells and through the influence of the microenvironment suggests that this pathway can be therapeutically exploited for the treatment of $\mathrm{Ph}^{+}$leukemias. Several small molecules inhibitors have been developed to target NF- $\kappa \mathrm{B}$-sustained cancers [84] and many of them have been tested in the context of $\mathrm{Ph}^{+}$leukemias (Figure 4). The first observations of the efficacy of NF- $\mathrm{B}$ targeting strategies come from $\mathrm{CML}$ and $\mathrm{Ph}^{+} \mathrm{ALL}$ cellular models and were obtained with BAY11-67082, an inhibitor of the I $\mathrm{B}-\alpha$ phosphorylation [66], and Bortezomib (PS-341), which blocks proteasomemediated I $\mathrm{B}-\alpha$ degradation [85-87]. Notably, the potential usage of Bortezomib in NF- $\mathrm{BB}$-dependent contexts should have high priority in the design of early clinical trials due to its availability for in-human use and previous acquired clinical experience. NF- $\mathrm{KB}$ inhibitors appear promising also in combination with other agents, in particular in combination with tyrosine kinase inhibitors. I $\kappa-\alpha$ degradation inhibition with Bortezomib synergizes with the pro-apoptotic effects of Imatinib, when the two drugs are administered sequentially [88], suggesting that this strategy could be used in those patients who exhibit a partial response to TKI. It was also shown that the IKK

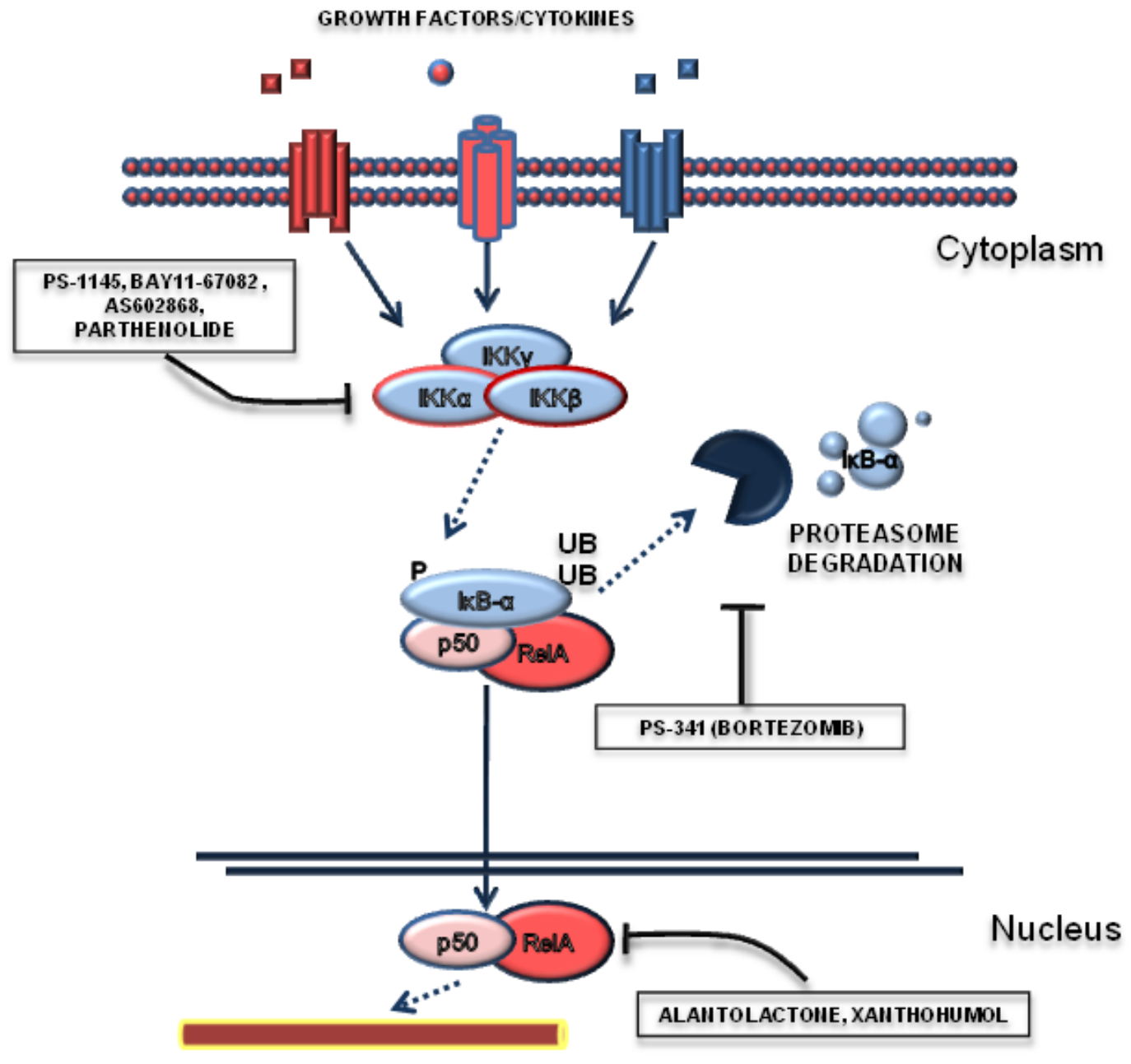

Figure 4: Targeting the NF-кB pathway. This Figure reports those drugs that have been shown to modulate $\mathrm{NF}^{-\kappa \mathrm{B}}$ in $\mathrm{Ph}^{+}$leukemias. In particular, NF- $\mathrm{KB}$ signaling can be modulated by IKK inhibitors (such as PS1145, BAY11-67082, AS602868), proteasome inhibitors (Bortezomid) or with drugs able to act at the transcriptional level (alantolactone, parthenolide). 
inhibitors PS-1145 [72] and AS602868 [89] are able to promote CML primary cells apoptosis. In particular AS602868 presents an increased efficacy in BCR-ABLT315I mutated cells [89]. In this specific cases, only Ponatinib is active against mutated Bcr-Abl kinase, although with a significant risk of major side effects [90]. Therefore, IKK inhibitors could be effective for the treatment of this specific mutation. Other compounds able to selectively target and inhibit NF- $\mathrm{B}$ pathway have been described to be effective in $\mathrm{Ph}^{+}$leukemias. In particular, Parthenolide has been shown to promote apoptosis of CML blast crisis cells [91], while Resveratrol [92], Xanthohumol [93], Curcumin [94], Alantolactone [95] were shown to be effective in other CML cell lines. Lastly, it is known that NF- $\kappa \mathrm{B}$ is able to promote resistance to chemotherapeutic agents. Conventional chemotherapy is still necessary for the treatment of $\mathrm{Ph}^{+} \mathrm{ALL}$ and CML blast crisis, due to reduced efficacy of TKI in these clinical scenarios. In line with these considerations, it was demonstrated that NF- $\kappa \mathrm{B}$ inhibition restores sensitivity to Etoposide, a chemotherapeutic agent [92]. Overall, we can assert that NF- $\mathrm{NB}$ signaling may be therapeutically attackable, offering the chance to achieve synthetic lethality with TKIs and to respond -at least in part- to the unmet clinical need in the field of $\mathrm{Ph}^{+}$leukemias.

\section{NEW TUMOR SUPPRESSIVE PERSPECTIVES: THE IKB- $\alpha /$ P53 CONNECTION}

We have recently investigated the contribution

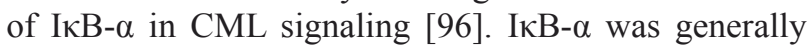
described as a tumor suppressor and found deleted in about $20 \%$ of glioblastomas [97] and mutated in some cases of Hodgkin diseases [98]. In the attempt to observe IкB- $\alpha$ under-expression/abnormal localization in CML, we ended up to highlight a sustained I $\mathrm{KB}-\alpha$ expression in CML primary samples [96]. Notably, we also observed that I $\kappa \mathrm{B}-\alpha$ is able to promote $\mathrm{p} 53$ nuclear exclusion in $\mathrm{CML}$ cells. IкB- $\alpha$ was previously reported to bind to both NF- $\kappa B$ and p53 [99-101]. Our data translated these observations in the setting of CML, describing a novel Bcr-Abl/IкB- $\alpha /$ p53 network, with potentially relevant implications for both tumorigenesis and therapy. In particular, Bcr-Abl/ I $\mathrm{B}-\alpha$ complex promotes the nuclear exclusion and consequent inactivation of p53 [96], an essential tumor suppressor [102]. I $\mathrm{KB}-\alpha$ can indeed be responsible for both the regulation of NF- $\mathrm{kB}$ and the triggering of $\mathrm{p} 53$ functional inactivation. Very recently, it was clearly demonstrated that CML CD34+ cells are characterized by the down-modulation of p53 targets and that drugs able to enhance p53 levels, together with c-MYC targeting drugs, promote CML cells selective apoptosis induction [103]. Indeed, the mechanisms of p53 modulation in CML pathogenesis appeared to be highly complex and, as a consequence, the development of strategies to reactivate p53 in CML and the effects of drugs that modulate IкB- $\alpha$ degradation (proteasome inhibitors) on p53 require further experimental investigations but may represent a new challenging approach to cure $\mathrm{Ph}+$ leukemias.

\section{DISCUSSION}

The NF- $\mathrm{kB}$ signal transduction is a very complex and stratified network, involving both canonical and non-canonical pathways and an integrated system of regulators. It plays an essential role in the pathogenesis of several cancers and offers several chances of therapeutic intervention with clinically available drugs. Almost 20 years ago, NF- $\mathrm{KB}$ was shown to play an essential role in the pathogenesis (and treatment) of $\mathrm{Ph}^{+}$positive leukemias. While few controversial results have been reported in different cellular models and primary $\mathrm{Ph}^{+}$ samples, the following conclusions can be summarized. 1) NF- $\mathrm{kB}$ is aberrantly activated in $\mathrm{Ph}^{+}$leukemias and in particular in CML blast phase and $\mathrm{Ph}^{+} \mathrm{ALL}$. The basal level of NF-kB activation in CML chronic phase is difficult to define accordingly to the methods of detection, samples management and appropriate controls. 2) Both $\mathrm{Bcr}-\mathrm{Abl}$ signaling and non-cell autonomous regulation by cytokines, such as TNF- $\alpha$ and TGF-beta, cooperate to promote NF- $\kappa \mathrm{B}$ activation in $\mathrm{Ph}^{+}$leukemia. The existence of these two mechanisms of NF- $\kappa B$ activation may explain the differences observed in various $\mathrm{Ph}^{+}$cell lines and primary cells: the removal of cells from the bone marrow environment could indeed affect the stromal contribution to NF- $\mathrm{KB}$ signaling. 3) In accordance to the previous point, murine modeling of NF- $\mathrm{kB}$ signaling in CML clearly demonstrates that IKK and IкB- $\alpha$ are mandatory to promote BCR-ABL tumorigenesis, ruling out the controversial results obtained in cell lines. 4) As observed in murine models, targeting IKK or preventing IkB- $\alpha$ degradation with proteasome inhibitors appear the best therapeutic interventions to inhibit NF-kB in $\mathrm{Ph}^{+}$ leukemias. Following the impressive results with the in vivo preclinical murine model, the association with TKI and IKK inhibitors should be tested with appropriate clinical trials to treat challenging $\mathrm{Ph}^{+}$leukemias, such as CML blast crisis and $\mathrm{Ph}^{+}$ALL. 5) Beside being a key NF$\kappa \mathrm{B}$ signaling inhibitor, IкB- $\alpha$ plays also an essential role in the regulation of $\mathrm{p} 53$ cellular compartmentalization and function, as we recently pointed out [96]. In particular, I $\mathrm{B}-\alpha$ acts at the crossroad between oncogenic signal (toward NF- $\mathrm{kB}$ ) and tumor suppressive signal (toward p53). 6) The NF-IкB pathway may also be attractive for its ability to modulate p53 activity, even if further experimental approaches are mandatory to investigate this challenging therapeutic opportunity in the treatment of $\mathrm{Ph}+$ leukemias.

As time has gone, during these 20 years the CML/ $\mathrm{NF}-\kappa \mathrm{B}$ relationship has become more mature and has offered different chances to investigate the contribution of 
this pathway in tumorigenesis and cancer therapy.

\section{ACKNOWLEDGMENTS}

This work was supported by the Italian Ministero della Salute - Ricerca finalizzata (Giovani Ricercatori) grant (code GR-2011-02351167) to A.M.

\section{CONFLICT OF INTEREST}

The authors declare no competing financial interests to disclose.

\section{REFERENCES}

1. Koretzky GA. The legacy of the Philadelphia chromosome. J Clin Invest. 2007; 117: 2030-2. doi: 10.1172/JCI33032.

2. Apperley JF. Chronic myeloid leukaemia. Lancet Lond Engl. 2015; 385: 1447-59. doi: 10.1016/S01406736(13)62120-0.

3. Ravandi F, Kebriaei P. Philadelphia chromosomepositive acute lymphoblastic leukemia. Hematol Oncol Clin North Am. 2009; 23: 1043-1063, vi. doi: 10.1016/j. hoc.2009.07.007.

4. Chereda B, Melo JV. Natural course and biology of CML. Ann Hematol. 2015; 94 Suppl 2: S107-121. doi: 10.1007/ s00277-015-2325-z.

5. Melo JV, Barnes DJ. Chronic myeloid leukaemia as a model of disease evolution in human cancer. Nat Rev Cancer. 2007; 7: 441-53. doi: 10.1038/nrc2147.

6. Saglio G, Morotti A, Mattioli G, Messa E, Giugliano E, Volpe G, Rege-Cambrin G, Cilloni D. Rational approaches to the design of therapeutics targeting molecular markers: the case of chronic myelogenous leukemia. Ann N Y Acad Sci. 2004; 1028: 423-31. doi: 10.1196/annals.1322.050.

7. Ren R. Mechanisms of BCR-ABL in the pathogenesis of chronic myelogenous leukaemia. Nat Rev Cancer. 2005; 5: 172-83. doi: 10.1038/nrc1567.

8. O'Hare T, Zabriskie MS, Eiring AM, Deininger MW. Pushing the limits of targeted therapy in chronic myeloid leukaemia. Nat Rev Cancer. 2012; 12: 513-26. doi: 10.1038/nrc3317.

9. Hantschel O, Superti-Furga G. Regulation of the c-Abl and Bcr-Abl tyrosine kinases. Nat Rev Mol Cell Biol. 2004; 5: 33-44. doi: 10.1038/nrm1280.

10. Melo JV. BCR-ABL gene variants. Baillières Clin Haematol. 1997; 10: 203-22.

11. Westbrook CA, Hooberman AL, Spino C, Dodge RK, Larson RA, Davey F, Wurster-Hill DH, Sobol RE, Schiffer C, Bloomfield CD. Clinical significance of the BCR-ABL fusion gene in adult acute lymphoblastic leukemia: a Cancer and Leukemia Group B Study (8762). Blood. 1992; 80: 2983-90.

12. Russo C, Carroll A, Kohler S, Borowitz M, Amylon
M, Homans A, Kedar A, Shuster J, Land V, Crist W. Philadelphia chromosome and monosomy 7 in childhood acute lymphoblastic leukemia: a Pediatric Oncology Group study. Blood. 1991; 77: 1050-6.

13. Suryanarayan K, Hunger SP, Kohler S, Carroll AJ, Crist W, Link MP, Cleary ML. Consistent involvement of the ber gene by $9 ; 22$ breakpoints in pediatric acute leukemias. Blood. 1991; 77: 324-30.

14. Morotti A, Fava C, Saglio G. Milestones and monitoring. Curr Hematol Malig Rep. 2015; 10: 167-72. doi: 10.1007/ s11899-015-0258-1.

15. Fava C, Morotti A, Dogliotti I, Saglio G, Rege-Cambrin G. Update on emerging treatments for chronic myeloid leukemia. Expert Opin Emerg Drugs. 2015; 20: 183-96. doi: 10.1517/14728214.2015.1031217.

16. Perl A, Carroll M. BCR-ABL kinase is dead; long live the CML stem cell. J Clin Invest. 2011; 121: 22-5. doi: 10.1172/JCI43605.

17. Morotti A, Panuzzo C, Fava C, Saglio G. Kinaseinhibitor-insensitive cancer stem cells in chronic myeloid leukemia. Expert Opin Biol Ther. 2014; 14: 287-99. doi: 10.1517/14712598.2014.867323.

18. Savona M, Talpaz M. Getting to the stem of chronic myeloid leukaemia. Nat Rev Cancer. 2008; 8: 341-50. doi: $10.1038 / \mathrm{nrc} 2368$.

19. Elrick LJ, Jorgensen HG, Mountford JC, Holyoake TL. Punish the parent not the progeny. Blood. 2005; 105: 18626. doi: 10.1182/blood-2004-08-3373.

20. Corbin AS, Agarwal A, Loriaux M, Cortes J, Deininger MW, Druker BJ. Human chronic myeloid leukemia stem cells are insensitive to imatinib despite inhibition of BCRABL activity. J Clin Invest. 2011; 121: 396-409. doi: 10.1172/JCI35721.

21. Radich JP. The biology of chronic myelogenous leukemia progression: who, what, where, and why? Hematol Oncol Clin North Am. 2011; 25: 967-980, v. doi: 10.1016/j. hoc.2011.09.002.

22. Malagola M, Papayannidis C, Baccarani M. Tyrosine kinase inhibitors in $\mathrm{Ph}+$ acute lymphoblastic leukaemia: facts and perspectives. Ann Hematol. 2016; 95: 681-93. doi: 10.1007/s00277-016-2617-y.

23. Kaelin WG. The concept of synthetic lethality in the context of anticancer therapy. Nat Rev Cancer. 2005; 5: 689-98. doi: $10.1038 / \mathrm{nrc} 1691$.

24. Ghosh S, May MJ, Kopp EB. NF-kappa B and Rel proteins: evolutionarily conserved mediators of immune responses. Annu Rev Immunol. 1998; 16: 225-60. doi: 10.1146/ annurev.immunol.16.1.225.

25. Bonizzi G, Karin M. The two NF-kappaB activation pathways and their role in innate and adaptive immunity. Trends Immunol. 2004; 25: 280-8. doi: 10.1016/j. it.2004.03.008.

26. Arkan MC, Greten FR. IKK- and NF-кB-mediated functions in carcinogenesis. Curr Top Microbiol Immunol. 
2011; 349: 159-69. doi: 10.1007/82_2010_97.

27. Perkins ND. The diverse and complex roles of NF-kB subunits in cancer. Nat Rev Cancer. 2012; 12: 121-32. doi: $10.1038 /$ nrc3204.

28. Guttridge DC, Albanese C, Reuther JY, Pestell RG, Baldwin AS. NF-kappaB controls cell growth and differentiation through transcriptional regulation of cyclin D1. Mol Cell Biol. 1999; 19: 5785-99.

29. Dutta J, Fan Y, Gupta N, Fan G, Gélinas C. Current insights into the regulation of programmed cell death by NF-kappaB. Oncogene. 2006; 25: 6800-16. doi: 10.1038/ sj.onc. 1209938 .

30. Luo J-L, Kamata H, Karin M. IKK/NF-kappaB signaling: balancing life and death--a new approach to cancer therapy. J Clin Invest. 2005; 115: 2625-32. doi: 10.1172/JCI26322.

31. Godwin P, Baird AM, Heavey S, Barr MP, O'Byrne KJ, Gately K. Targeting nuclear factor-kappa B to overcome resistance to chemotherapy. Front Oncol. 2013; 3: 120. doi: 10.3389/fonc. 2013.00120 .

32. Gupta SC, Sundaram C, Reuter S, Aggarwal BB. Inhibiting NF- $\kappa \mathrm{B}$ activation by small molecules as a therapeutic strategy. Biochim Biophys Acta. 2010; 1799: 775-87. doi: 10.1016/j.bbagrm.2010.05.004

33. Lin Y, Bai L, Chen W, Xu S. The NF-kappaB activation pathways, emerging molecular targets for cancer prevention and therapy. Expert Opin Ther Targets. 2010; 14: 45-55. doi: 10.1517/14728220903431069.

34. Hamdane M, David-Cordonnier MH, D'Halluin JC. Activation of p65 NF-kappaB protein by p210BCR-ABL in a myeloid cell line (P210BCR-ABL activates p65 NFkappaB). Oncogene. 1997; 15: 2267-75. doi: 10.1038/ sj.onc.1201411.

35. Reuther JY, Reuther GW, Cortez D, Pendergast AM, Baldwin AS. A requirement for NF-kappaB activation in Bcr-Abl-mediated transformation. Genes Dev. 1998; 12: 968-81.

36. Kirchner D, Duyster J, Ottmann O, Schmid RM, Bergmann L, Munzert G. Mechanisms of Bcr-Abl-mediated NFkappaB/Rel activation. Exp Hematol. 2003; 31: 504-11.

37. Xia Y, Shen S, Verma IM. NF- $\kappa B$, an active player in human cancers. Cancer Immunol Res. 2014; 2: 823-30. doi: 10.1158/2326-6066.CIR-14-0112.

38. Jing $\mathrm{H}$, Lee $\mathrm{S}$. NF- $\kappa \mathrm{B}$ in cellular senescence and cancer treatment. Mol Cells. 2014; 37: 189-95. doi: 10.14348/ molcells.2014.2353.

39. Karin M. Nuclear factor-kappaB in cancer development and progression. Nature. 2006; 441: 431-6. doi: 10.1038/ nature04870.

40. Hayden MS, Ghosh S. NF- $\kappa B$, the first quarter-century: remarkable progress and outstanding questions. Genes Dev. 2012; 26: 203-34. doi: 10.1101/gad.183434.111.

41. Hoesel B, Schmid JA. The complexity of NF- $\kappa$ B signaling in inflammation and cancer. Mol Cancer. 2013; 12: 86. doi: 10.1186/1476-4598-12-86.
42. Bradford JW, Baldwin AS. IKK/nuclear factor-kappaB and oncogenesis: roles in tumor-initiating cells and in the tumor microenvironment. Adv Cancer Res. 2014; 121: 125-45. doi: 10.1016/B978-0-12-800249-0.00003-2.

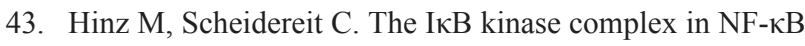
regulation and beyond. EMBO Rep. 2014; 15: 46-61. doi: 10.1002/embr.201337983.

44. Senegas A, Gautheron J, Maurin AGD, Courtois G. IKKrelated genetic diseases: probing $\mathrm{NF}-\kappa \mathrm{B}$ functions in humans and other matters. Cell Mol Life Sci CMLS. 2015; 72: 1275-87. doi: 10.1007/s00018-014-1793-y.

45. Israël A. The IKK complex, a central regulator of NFkappaB activation. Cold Spring Harb Perspect Biol. 2010; 2: a000158. doi: 10.1101/cshperspect.a000158.

46. Karin M. The IkappaB kinase - a bridge between inflammation and cancer. Cell Res. 2008; 18: 334-42. doi: 10.1038/cr.2008.30.

47. Werner SL, Barken D, Hoffmann A. Stimulus specificity of gene expression programs determined by temporal control of IKK activity. Science. 2005; 309: 1857-61. doi: 10.1126/ science. 1113319.

48. O’Dea EL, Barken D, Peralta RQ, Tran KT, Werner SL, Kearns JD, Levchenko A, Hoffmann A. A homeostatic model of IkappaB metabolism to control constitutive NFkappaB activity. Mol Syst Biol. 2007; 3: 111. doi: 10.1038/ msb4100148.

49. Sun S-C. Non-canonical NF-кB signaling pathway. Cell Res. 2011; 21: 71-85. doi: 10.1038/cr.2010.177.

50. Sun S-C. The noncanonical NF- $\kappa \mathrm{B}$ pathway. Immunol Rev. 2012; 246: 125-40. doi: 10.1111/j.1600065X.2011.01088.x.

51. Espinosa L, Margalef P, Bigas A. Non-conventional functions for NF- $\kappa \mathrm{B}$ members: the dark side of NF- $\kappa \mathrm{B}$. Oncogene. 2015; 34: 2279-87. doi: 10.1038/onc.2014.188.

52. Kucharczak J, Simmons MJ, Fan Y, Gélinas C. To be, or not to be: NF-kappaB is the answer--role of Rel/NF-kappaB in the regulation of apoptosis. Oncogene. 2003; 22: 896182. doi: 10.1038/sj.onc.1207230.

53. Ledoux AC, Perkins ND. NF- $\kappa$ B and the cell cycle. Biochem Soc Trans. 2014; 42: 76-81. doi: 10.1042/ BST20130156.

54. Huber MA, Azoitei N, Baumann B, Grünert S, Sommer A, Pehamberger H, Kraut N, Beug H, Wirth T. NF-kappaB is essential for epithelial-mesenchymal transition and metastasis in a model of breast cancer progression. J Clin Invest. 2004; 114: 569-81. doi: 10.1172/JCI21358.

55. Gasparini C, Celeghini C, Monasta L, Zauli G. NF-кB pathways in hematological malignancies. Cell Mol Life Sci CMLS. 2014; 71: 2083-102. doi: 10.1007/s00018-0131545-4.

56. Zhou J, Ching YQ, Chng W-J. Aberrant nuclear factorkappa B activity in acute myeloid leukemia: from molecular pathogenesis to therapeutic target. Oncotarget. 2015; 6: 5490-500. doi: 10.18632/oncotarget.3545. 
57. Demchenko YN, Kuehl WM. A critical role for the NFkB pathway in multiple myeloma. Oncotarget. 2010; 1: 59-68. doi: 10.18632/oncotarget.109.

58. Dejardin E. The alternative NF-kappaB pathway from biochemistry to biology: pitfalls and promises for future drug development. Biochem Pharmacol. 2006; 72: 116179. doi: 10.1016/j.bcp.2006.08.007.

59. Shostak K, Chariot A. EGFR and NF-кB: partners in cancer. Trends Mol Med. 2015; 21: 385-93. doi: 10.1016/j. molmed.2015.04.001.

60. Müller M, Morotti A, Ponzetto C. Activation of NFkappaB is essential for hepatocyte growth factor-mediated proliferation and tubulogenesis. Mol Cell Biol. 2002; 22: 1060-72.

61. Finco TS, Westwick JK, Norris JL, Beg AA, Der CJ, Baldwin AS. Oncogenic Ha-Ras-induced signaling activates NF-kappaB transcriptional activity, which is required for cellular transformation. J Biol Chem. 1997; 272: 24113-6.

62. Bassères DS, Ebbs A, Levantini E, Baldwin AS. Requirement of the NF-kappaB subunit p65/RelA for K-Ras-induced lung tumorigenesis. Cancer Res. 2010; 70: 3537-46. doi: 10.1158/0008-5472.CAN-09-4290.

63. Reddy SA, Huang JH, Liao WS. Phosphatidylinositol 3-kinase as a mediator of TNF-induced NF-kappa B activation. J Immunol Baltim Md 1950. 2000; 164: 135563.

64. Madrid LV, Mayo MW, Reuther JY, Baldwin AS. Akt stimulates the transactivation potential of the RelA/p65 Subunit of NF-kappa B through utilization of the Ikappa $\mathrm{B}$ kinase and activation of the mitogen-activated protein kinase p38. J Biol Chem. 2001; 276: 18934-40. doi: 10.1074/jbc.M101103200.

65. Shain KH, Jove R, Olashaw NE. Constitutive RelB activation in $\mathrm{v}$-Src-transformed fibroblasts: requirement for IkappaB degradation. J Cell Biochem. 1999; 73: 237-47.

66. Baron F, Turhan AG, Giron-Michel J, Azzarone B, Bentires-Alj M, Bours V, Bourhis JH, Chouaib S, Caignard A. Leukemic target susceptibility to natural killer cytotoxicity: relationship with BCR-ABL expression. Blood. 2002; 99: 2107-13.

67. Nawata R, Yujiri T, Nakamura Y, Ariyoshi K, Takahashi T, Sato Y, Oka Y, Tanizawa Y. MEK kinase 1 mediates the antiapoptotic effect of the Bcr-Abl oncogene through NF-kappaB activation. Oncogene. 2003; 22: 7774-80. doi: 10.1038/sj.onc.1206901.

68. Mihailovic T, Marx M, Auer A, Van Lint J, Schmid M, Weber C, Seufferlein T. Protein kinase D2 mediates activation of nuclear factor kappaB by Bcr-Abl in BcrAbl+ human myeloid leukemia cells. Cancer Res. 2004; 64: 8939-44. doi: 10.1158/0008-5472.CAN-04-0981.

69. Vejda S, Piwocka K, McKenna SL, Cotter TG. Autocrine secretion of osteopontin results in degradation of I kappa $\mathrm{B}$ in Bcr-Abl-expressing cells. Br J Haematol. 2005; 128: 711-21. doi: 10.1111/j.1365-2141.2004.05355.x.
70. Zhang H, Chang G, Wang J, Lin Y, Ma L, Pang T. CUEDC2 sensitizes chronic myeloid leukemic cells to imatinib treatment. Leuk Res. 2013; 37: 1583-91. doi: 10.1016/j.leukres.2013.08.019.

71. Bueso-Ramos CE, Rocha FC, Shishodia S, Medeiros LJ, Kantarjian HM, Vadhan-Raj S, Estrov Z, Smith TL, Nguyen MH, Aggarwal BB. Expression of constitutively active nuclear-kappa B RelA transcription factor in blasts of acute myeloid leukemia. Hum Pathol. 2004; 35: 246-53.

72. Cilloni D, Messa F, Arruga F, Defilippi I, Morotti A, Messa E, Carturan S, Giugliano E, Pautasso M, Bracco E, Rosso V, Sen A, Martinelli G, et al. The NF-kappaB pathway blockade by the IKK inhibitor PS1145 can overcome imatinib resistance. Leukemia. 2006; 20: 61-7. doi: 10.1038/sj.leu.2403998.

73. Munzert G, Kirchner D, Ottmann O, Bergmann L, Schmid RM. Constitutive NF-kappab/Rel activation in philadelphia chromosome positive $(\mathrm{Ph}+)$ acute lymphoblastic leukemia (ALL). Leuk Lymphoma. 2004; 45: 1181-4.

74. Gerondakis S, Grumont R, Gugasyan R, Wong L, Isomura I, Ho W, Banerjee A. Unravelling the complexities of the NF-kappaB signalling pathway using mouse knockout and transgenic models. Oncogene. 2006; 25: 6781-99. doi: 10.1038/sj.onc.1209944.

75. Pasparakis M, Luedde T, Schmidt-Supprian M. Dissection of the NF-kappaB signalling cascade in transgenic and knockout mice. Cell Death Differ. 2006; 13: 861-72. doi: 10.1038/sj.cdd.4401870.

76. Hsieh M-Y, Van Etten RA. IKK-dependent activation of NF- $\kappa \mathrm{B}$ contributes to myeloid and lymphoid leukemogenesis by BCR-ABL1. Blood. 2014; 123: 240111. doi: 10.1182/blood-2014-01-547943.

77. Hayden MS, Ghosh S. Regulation of NF- $\mathrm{BB}$ by TNF family cytokines. Semin Immunol. 2014; 26: 253-66. doi: 10.1016/j.smim.2014.05.004.

78. Mukhopadhyay A, Shishodia S, Suttles J, Brittingham K, Lamothe B, Nimmanapalli R, Bhalla KN, Aggarwal BB. Ectopic expression of protein-tyrosine kinase BcrAbl suppresses tumor necrosis factor (TNF)-induced NFkappa B activation and IkappaBalpha phosphorylation. Relationship with down-regulation of TNF receptors. J Biol Chem. 2002; 277: 30622-8. doi: 10.1074/jbc.M204748200.

79. Gallipoli P, Pellicano F, Morrison H, Laidlaw K, Allan EK, Bhatia R, Copland M, Jørgensen HG, Holyoake TL. Autocrine TNF- $\alpha$ production supports CML stem and progenitor cell survival and enhances their proliferation. Blood. 2013; 122: 3335-9. doi: 10.1182/ blood-2013-02-485607.

80. Miyazono K. Tumour promoting functions of TGF- $\beta$ in CML-initiating cells. J Biochem (Tokyo). 2012; 152: 383 5. doi: 10.1093/jb/mvs 106 .

81. Naka K, Hoshii T, Muraguchi T, Tadokoro Y, Ooshio T, Kondo Y, Nakao S, Motoyama N, Hirao A. TGF-betaFOXO signalling maintains leukaemia-initiating cells in 
chronic myeloid leukaemia. Nature. 2010; 463: 676-80. doi: 10.1038/nature08734.

82. Fogli M, Carlo-Stella C, Curti A, Ratta M, Tazzari PL, Ragazzi E, Colla S, Santucci AM, Tura S, Lemoli RM. Transforming growth factor beta3 inhibits chronic myelogenous leukemia hematopoiesis by inducing Fasindependent apoptosis. Exp Hematol. 2000; 28: 775-83.

83. Zhu X, Wang L, Zhang B, Li J, Dou X, Zhao RC. TGFbeta1-induced PI3K/Akt/NF-kappaB/MMP9 signalling pathway is activated in Philadelphia chromosome-positive chronic myeloid leukaemia hemangioblasts. J Biochem (Tokyo). 2011; 149: 405-14. doi: 10.1093/jb/mvr016.

84. Arepalli SK, Choi M, Jung J-K, Lee H. Novel NF-кB inhibitors: a patent review (2011 - 2014). Expert Opin Ther Pat. 2015; 25: 319-34. doi: 10.1517/13543776.2014.998199.

85. Yu C, Rahmani M, Conrad D, Subler M, Dent P, Grant S. The proteasome inhibitor bortezomib interacts synergistically with histone deacetylase inhibitors to induce apoptosis in $\mathrm{Bcr} / \mathrm{Abl}+$ cells sensitive and resistant to STI571. Blood. 2003; 102: 3765-74. doi: 10.1182/ blood-2003-03-0737.

86. Dai Y, Rahmani M, Pei X-Y, Dent P, Grant S. Bortezomib and flavopiridol interact synergistically to induce apoptosis in chronic myeloid leukemia cells resistant to imatinib mesylate through both Bcr/Abl-dependent and -independent mechanisms. Blood. 2004; 104: 509-18. doi: 10.1182/ blood-2003-12-4121.

87. Albero MP, Vaquer JM, Andreu EJ, Villanueva JJ, Franch L, Ivorra C, Poch E, Agirre X, Prosper F, Pérez-Roger I. Bortezomib decreases $\mathrm{Rb}$ phosphorylation and induces caspase-dependent apoptosis in Imatinib-sensitive and -resistant Bcr-Abl1-expressing cells. Oncogene. 2010; 29: 3276-86. doi: 10.1038/onc.2010.81.

88. Gatto S, Scappini B, Pham L, Onida F, Milella M, Ball G, Ricci C, Divoky V, Verstovsek S, Kantarjian HM, Keating MJ, Cortes-Franco JE, Beran M. The proteasome inhibitor PS-341 inhibits growth and induces apoptosis in Bcr/ Abl-positive cell lines sensitive and resistant to imatinib mesylate. Haematologica. 2003; 88: 853-63.

89. Lounnas N, Frelin C, Gonthier N, Colosetti P, Sirvent A, Cassuto J-P, Berthier F, Sirvent N, Rousselot P, Dreano M, Peyron J-F, Imbert V. NF-kappaB inhibition triggers death of imatinib-sensitive and imatinib-resistant chronic myeloid leukemia cells including T315I Bcr-Abl mutants. Int J Cancer J Int Cancer. 2009; 125: 308-17. doi: 10.1002/ ijc. 24294.

90. Cortes JE, Kim D-W, Pinilla-Ibarz J, le Coutre P, Paquette R, Chuah C, Nicolini FE, Apperley JF, Khoury HJ, Talpaz M, DiPersio J, DeAngelo DJ, Abruzzese E, et al. A phase 2 trial of ponatinib in Philadelphia chromosome-positive leukemias. N Engl J Med. 2013; 369: 1783-96. doi: 10.1056/NEJMoa1306494.

91. Guzman ML, Rossi RM, Karnischky L, Li X, Peterson DR, Howard DS, Jordan CT. The sesquiterpene lactone parthenolide induces apoptosis of human acute myelogenous leukemia stem and progenitor cells. Blood. 2005; 105: 4163-9. doi: 10.1182/blood-2004-10-4135.

92. Morotti A, Cilloni D, Pautasso M, Messa F, Arruga F, Defilippi I, Carturan S, Catalano R, Rosso V, Chiarenza A, Taulli R, Bracco E, Rege-Cambrin G, et al. NF-kB inhibition as a strategy to enhance etoposide-induced apoptosis in K562 cell line. Am J Hematol. 2006; 81: 938-45. doi: 10.1002/ajh.20732.

93. Monteghirfo S, Tosetti F, Ambrosini C, Stigliani S, Pozzi S, Frassoni F, Fassina G, Soverini S, Albini A, Ferrari N. Antileukemia effects of xanthohumol in Bcr/Abltransformed cells involve nuclear factor-kappaB and p53 modulation. Mol Cancer Ther. 2008; 7: 2692-702. doi: 10.1158/1535-7163.MCT-08-0132.

94. Reuter S, Charlet J, Juncker T, Teiten M-H, Dicato M, Diederich M. Effect of curcumin on nuclear factor kappaB signaling pathways in human chronic myelogenous K562 leukemia cells. Ann N Y Acad Sci. 2009; 1171: 436-47. doi: 10.1111/j.1749-6632.2009.04731.x.

95. Wei W, Huang H, Zhao S, Liu W, Liu C-X, Chen L, Li J-M, $\mathrm{Wu}$ Y-L, Yan H. Alantolactone induces apoptosis in chronic myelogenous leukemia sensitive or resistant to imatinib through NF- $\kappa \mathrm{B}$ inhibition and $\mathrm{Bcr} / \mathrm{Abl}$ protein deletion. Apoptosis Int J Program Cell Death. 2013; 18: 1060-70. doi: 10.1007/s10495-013-0854-2.

96. Crivellaro S, Panuzzo C, Carrà G, Volpengo A, Crasto F, Gottardi E, Familiari U, Papotti M, Torti D, Piazza R, Redaelli S, Taulli R, Guerrasio A, et al. Non genomic loss of function of tumor suppressors in CML: BCR-ABL promotes I $\mathrm{B} \alpha$ mediated p53 nuclear exclusion. Oncotarget. 2015; 6: 25217-25. doi: 10.18632/oncotarget.4611.

97. Bredel M, Scholtens DM, Yadav AK, Alvarez AA, Renfrow JJ, Chandler JP, Yu ILY, Carro MS, Dai F, Tagge MJ, Ferrarese R, Bredel C, Phillips HS, et al. NFKBIA deletion in glioblastomas. N Engl J Med. 2011; 364: 627-37. doi: 10.1056/NEJMoa1006312.

98. Lake A, Shield LA, Cordano P, Chui DTY, Osborne J, Crae S, Wilson KS, Tosi S, Knight SJL, Gesk S, Siebert R, Hay RT, Jarrett RF. Mutations of NFKBIA, encoding IkappaB alpha, are a recurrent finding in classical Hodgkin lymphoma but are not a unifying feature of non-EBV-associated cases. Int J Cancer. 2009; 125: 1334-42. doi: 10.1002/ijc.24502.

99. Chang N-S. The non-ankyrin C terminus of Ikappa Balpha physically interacts with p53 in vivo and dissociates in response to apoptotic stress, hypoxia, DNA damage, and transforming growth factor-beta 1-mediated growth suppression. J Biol Chem. 2002; 277: 10323-31. doi: 10.1074/jbc.M106607200.

100. Dreyfus DH, Nagasawa M, Gelfand EW, Ghoda LY. Modulation of p53 activity by IkappaBalpha: evidence suggesting a common phylogeny between NF-kappaB and p53 transcription factors. BMC Immunol. 2005; 6: 12. doi: 10.1186/1471-2172-6-12.

101. Li X, Xing D, Wang J, Zhu D-B, Zhang L, Chen X-J, Sun F-Y, Hong A. Effects of IkappaBalpha and its mutants 
on NF-kappaB and p53 signaling pathways. World J Gastroenterol. 2006; 12: 6658-64.

102. Bieging KT, Mello SS, Attardi LD. Unravelling mechanisms of p53-mediated tumour suppression. Nat Rev Cancer. 2014; 14: 359-70. doi: 10.1038/nrc3711.
103. Abraham SA, Hopcroft LEM, Carrick E, Drotar ME, Dunn K, Williamson AJK, Korfi K, Baquero P, Park LE, Scott MT, Pellicano F, Pierce A, Copland M, et al. Dual targeting of p53 and c-MYC selectively eliminates leukaemic stem cells. Nature. 2016; 534: 341-6. doi: 10.1038/nature18288. 